News and Views

\title{
Preliminary notes on a newly discovered skull of the extinct monkey Antillothrix from Hispaniola and the origin of the Greater Antillean monkeys
}

\author{
Richard F. Kay $^{\mathrm{a}, *}$, Kevin D. Hunt ${ }^{\mathrm{b}}$, Charles D. Beeker ${ }^{\mathrm{b}, \mathrm{c}}$, Geoffrey W. Conrad ${ }^{\mathrm{b}, \mathrm{d}}$, Claudia C. Johnson ${ }^{\mathrm{e}}$, \\ Jessica Keller ${ }^{\mathrm{c}}$ \\ a Department of Evolutionary Anthropology, Duke University, Durham, North Carolina 27708, USA \\ ${ }^{\mathrm{b}}$ Department of Anthropology, Indiana University, Bloomington, Indiana 47405-7100, USA \\ ${ }^{c}$ Office of Underwater Science, School of Health, Physical Education and Recreation, Indiana University, Bloomington, Indiana 47405, USA \\ ${ }^{\mathrm{d}}$ William Hammond Mathers Museum, Indiana University, Bloomington, Indiana 47408-3812, USA \\ e Department of Geological Sciences, Indiana University, Bloomington, Indiana 47405-1405, USA
}

\section{A $\quad$ R $T$ T I C L E E I N F O}

\section{Article history:}

Received 26 April 2010

Accepted 4 September 2010

\section{Keywords:}

Platyrrhini

Anthropoidea

West Indies

Primate evolution

Paleontology

\section{Introduction}

In July 2009, a team from Indiana University discovered a spectacularly preserved cranium of an extinct platyrrhine primate of middle Holocene age in the Padre Nuestro underwater cavern complex, southeastern Dominican Republic, Hispaniola (Fig. 1).

The skull (specimen number PNE-PNP-PN-09-01, PN-09-01 ${ }^{1}$ for short; Fig. 2) is referred to Antillothrix bernensis, and until recently was known only from a few jaw fragments and teeth. Here, we place the discovery on record, briefly describe the pertinent information about the cavern and its associations, and offer some comments on its phylogenetic affiliations and adaptations. PN-0901 was recovered from the Padre Nuestro cavern, part of an interconnected cave complex accessible through several openings of which Padre Nuestro is one (Conrad et al., 2001; Beeker et al., 2002). The cavern entrance is $<10 \mathrm{~m}$ above sea level. Explored parts are filled with fresh water, but travertine formations are

\footnotetext{
* Corresponding author.

E-mail address: richard.kay@duke.edu (R.F. Kay).

1 Abreviations: PNE-PNP: Parque Nacional Del Este-Padre Nuestro Park. CENDIA: Centro Dominicano de investigaciones Anthropológicas, UASD; MHD: Museo del Hombre Dominicano.
}

present that only form in dry conditions. The fossil material was found $<50 \mathrm{~m}$ from the cavern entrance at water depths of 5-10 m. Also recovered were fragments of carbonized wood, flaked stone tools, and thousands of bones of extinct sloths, caviomorph rodents, soricomorphs, fish, birds, reptiles, and terrestrial and nearshore marine gastropods. Several lines of evidence suggest that this material is no younger than mid-Holocene.

First, a working hypothesis is that the cave drowned 6,500 years $\mathrm{BP}$ when worldwide sea levels rose to within $3 \mathrm{~m}$ of current levels, having risen $22 \mathrm{~m}$ in the preceding 1500 years (Fleming et al., 1998). Curtis et al. (2001) suggest that as the Holocene progressed, water levels in such caves responded to global sea level changes, rather than merely to local hydrologic changes.

Second, pre-ceramic "Casimiroid" lithics also occur deep in the cave, but ceramics occur only at the very front in $<1 \mathrm{~m}$ of water. The earliest reported radiometrically dated human occupation of Hispaniola of the "Casimiroid" type is 5780-6180 yrs BP (Veloz Maggiolo and Vega, 1982; Moore, 1991; Wilson et al., 1998; MacPhee et al., 2007; Wilson, 2007).

Third, while PN-09-01 is undated, remains of the extinct sloths referable to Acratocnus and Parocnus (McDonald, personal communication; Keller, 2009) were found in close association. The only dated occurrence of these taxa in Hispaniola is a date for Parocnus at Trouing Gallery that is greater than 14,200 years BP (Steadman et al., 2005).

Lastly, the type specimen of Antillothrix bernensis (CENDIA- ${ }^{1}$ ) (Rímoli, 1977) was dated at 3,850 \pm 135 BP. This date should be considered a minimum age because the dated plant material came from a stratigraphic level $10-20 \mathrm{~cm}$ above the primate and other vertebrate remains and is not associated with human activities (Rímoli, 1977).

\section{The Skull}

PN-09-01 (Fig. 2) is the best preserved primate cranium and only the third skull of any primate found in the Greater Antilles. A skull of Paralouatta (see below) from Cuba is more fragmentary. The fossil record of primates from the island of Hispaniola is particularly poor. 


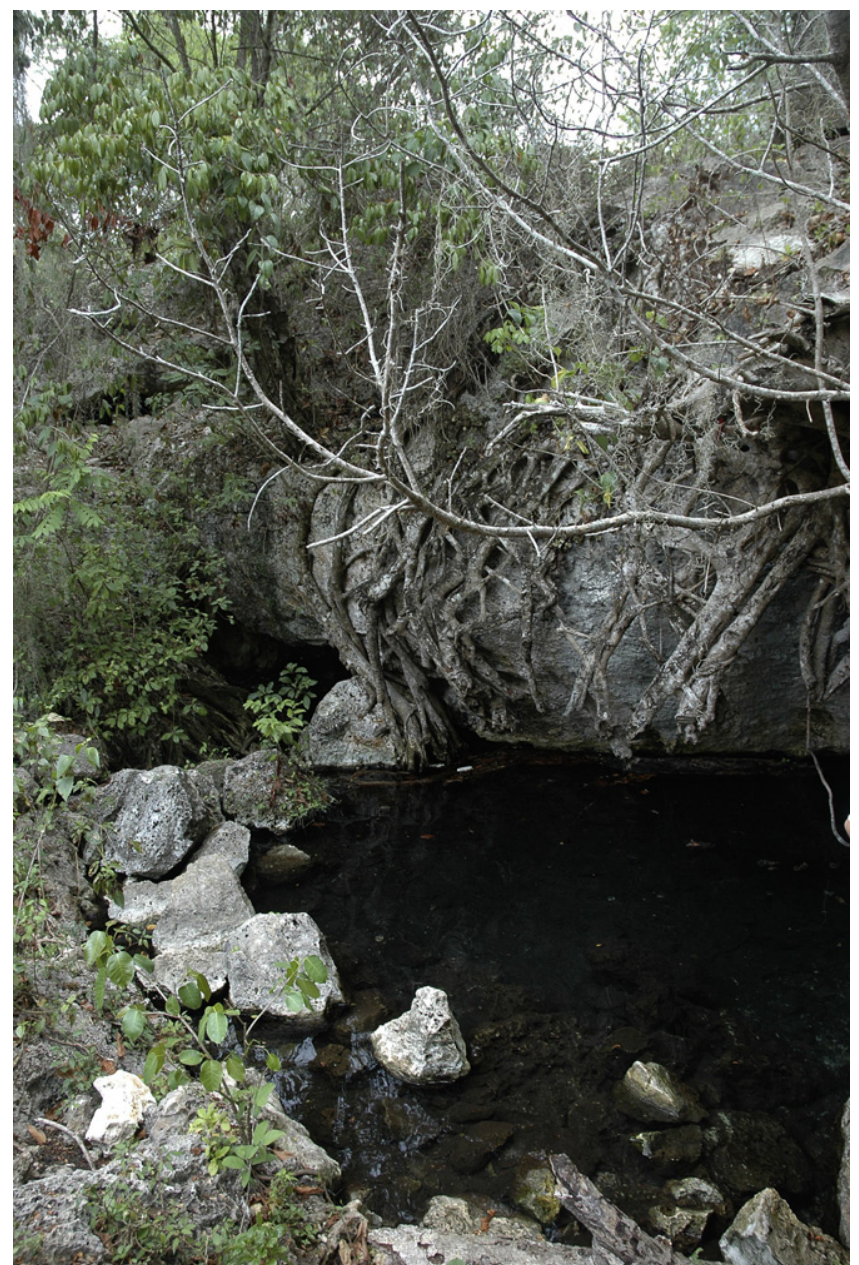

Figure 1. Entrance to the Padre Nuestro cave, a part of the Padre Nuestro cave complex in southeastern Dominican Republic

The only extinct species formally described is Antillothrix bernensis, based on the type maxilla preserving $\mathrm{P}^{3}-\mathrm{M}^{1}$, root sockets for $\mathrm{C}^{1}$ and $\mathrm{P}^{2}$, and a referred fragmentary mandible with $\mathrm{M}_{2}$ (Rímoli, 1977; MacPhee and Woods, 1982; MacPhee et al., 1995). Another specimen consisting of a skull reassembled from fragments, associated with postcranial bones of a young adult Antillothrix, was reported after submission of this manuscript (Rosenberger et al., 2010).

The type maxilla of Antillothrix bernensis is directly comparable with PN-09-1, making allocation to that species secure. The tooth crown dimensions and proportions of $\mathrm{P}^{4}-\mathrm{M}^{2}$ of the type and referred specimen are within $10 \%$ of one another. $\mathrm{P}^{4}$ of CENDIA- 1 is $12 \%$ buccolingually broader than PN-09-1. Similar within species variability is encountered in ten specimens of Cebus capucinus. Judging from the root sockets of the $\mathrm{C}-\mathrm{P}^{3}$, the proportions of the anterior teeth are likewise similar: the canine socket is as large as that of the $\mathrm{M}^{1}$; alveoli of a single-rooted $\mathrm{P}^{2}$ and two-rooted $\mathrm{P}^{3}$ follow a graded size increase with respect to $\mathrm{P}^{4}$. In both specimens, $\mathrm{P}^{4}$ has two cusps and a poorly developed lingual cingulum. In both specimens, $\mathrm{M}^{1}$ is larger than $\mathrm{M}^{2}$. $\mathrm{M}^{1}$ and $\mathrm{M}^{2}$ have four principal cusps. A distolingually positioned hypocone is supported by a strong lingual cingulum that wraps lingually around the protocone and is separated from the trigone by a pronounced sulcus. All teeth have weak buccal cingula. Accessory cusps also are weak $\left(\mathrm{M}^{1}\right.$ paraconule) and/or absent ( $\mathrm{M}^{1}-\mathrm{M}^{2}$ metaconule). The length and sharpness of the cusps and crests is moderate, comparable with those of extant Pithecia or Cebus.

\section{Phylogenetic and biogeographic hypotheses}

Three genera of extinct platyrrhines are known in the Greater Antilles-one each from Cuba, Jamaica, and Hispaniola.

Paralouatta, from the late Quaternary of Cuba, is known from the skull of an old individual, unassociated postcranial bones, and isolated teeth (Rivero and Arredondo, 1991; Horovitz and MacPhee, 1999; MacPhee and Meldrum, 2006). A talus from the late early Miocene of Cuba (MacPhee et al., 2003) is referred to Paralouatta marianae (MacPhee, 2009). Some regard Paralouatta to be closely related to the living howler monkey, Alouatta (Rivero and Arredondo, 1991; Rosenberger, 2002). Others hold that resemblances between Alouatta and Paralouatta are homoplastic and that the latter forms a clade with Xenothrix and Antillothrix (see below) (Horovitz, 1999; Horovitz and MacPhee, 1999).

Holocene-aged Xenothrix from Jamaica is documented from several mandibles, a palate, and limb bones (Williams and Koopman, 1952; Rosenberger, 1977, 2002; MacPhee and Fleagle, 1991; MacPhee and Horovitz, 2004; MacPhee and Meldrum, 2006). Rosenberger (1977) and Rosenberger et al. (1990) identified a combination of dental and mandibular features that support an affiliation with the living pitheciid, Callicebus. Ford and Morgan (1986) thought that Xenothrix, by virtue of its reduced molar formula, might be a large callitrichine. Based upon the larger sample, Horovitz and colleagues (Horovitz, 1999; MacPhee and Horovitz, 2004; MacPhee and Meldrum, 2006) agree with Rosenberger (1977) that Xenothrix is related to Callicebus. They demonstrate that Xenothrix does not have large orbits, as Rosenberger (2002) claimed, and therefore shows no special similarity to Aotus.

The Hispaniolan monkey Antillothrix was, until 2010, the most poorly known Greater Antillean monkey. The first specimen was described as a new species of Saimiri by Rímoli (1977). MacPhee and Woods (1982) agreed that CENDIA-1 is cebine, but elevated it to a new genus, Antillothrix. Some researchers continue to regard Antillothrix as a cebine (Saimiri plus Cebus) (Rosenberger, 2002; Rosenberger et al., 2010), while others combine Antillothrix, Paralouatta and Xenothrix into a clade that they consider to be a sistertaxon to Callicebus (MacPhee et al., 1995; Horovitz, 1999; MacPhee and Horovitz, 2004) (Fig. 3).

PN-09-01 evinces a number of features at odds with all current phylogenetic views. Antillothrix lacks a host of shared-derived cranial features that characterize crown cebines (Cebus and Saimiri). As noted by Rosenberger (1979), cebines have unusually narrow interorbital regions, dorsoventrally narrow zygomatic arches, shallow glenoid fossae, and weak postglenoid processes. The cebine brain is disproportionally large for a platyrrhine (Isler et al., 2008) and the neocortex is expanded over the olfactory bulbs. The outer table of the frontal conforms to the profile of the neocortex (Kay and Fleagle, 2010). Posterior expansion of the brain has repositioned the foramen magnum beneath the braincase, yielding a quite horizontal nuchal plane. Also, perhaps as a consequence of brain enlargement (Ross and Ravosa, 1993), the cebine angle of basicranial flexion is relatively acute, producing a pronounced klinorhynchy.

PN-09-01 has none of the above mentioned crown cebine features. Its interorbital region is broad and glabella is broadly separated from a relatively small frontal cortex by a thick layer of spongy bone (a frontal sinus is not present). The zygomatic arch is dorsoventrally deep, and a very strong postglenoid process borders the glenoid fossa posteriorly. The nuchal plane is oriented quite vertically, and the angle of basicranial flexion is distinctly airorhynch. Some of the features of the new skull (the robusticity of the zygomatic arch and the degree of cranial flexure) are unknown hitherto-the area is broken away in the recently described specimen MHD-01 ${ }^{1}$ (Rosenberger et al., 2010). PN-09-01 and MHD-01 apparently differ in several features. Rosenberger et al. (2010) 

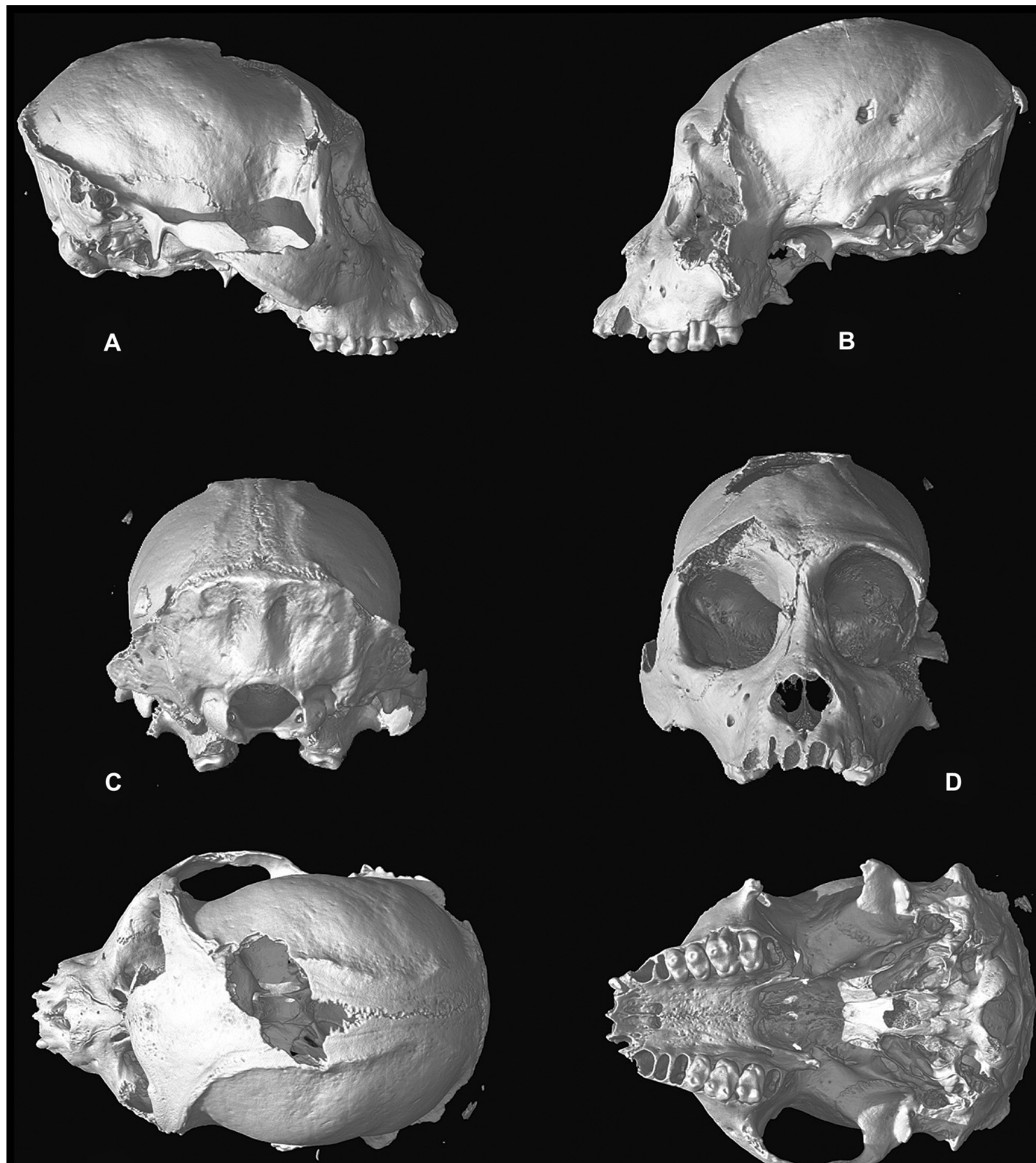

$\mathbf{E}$

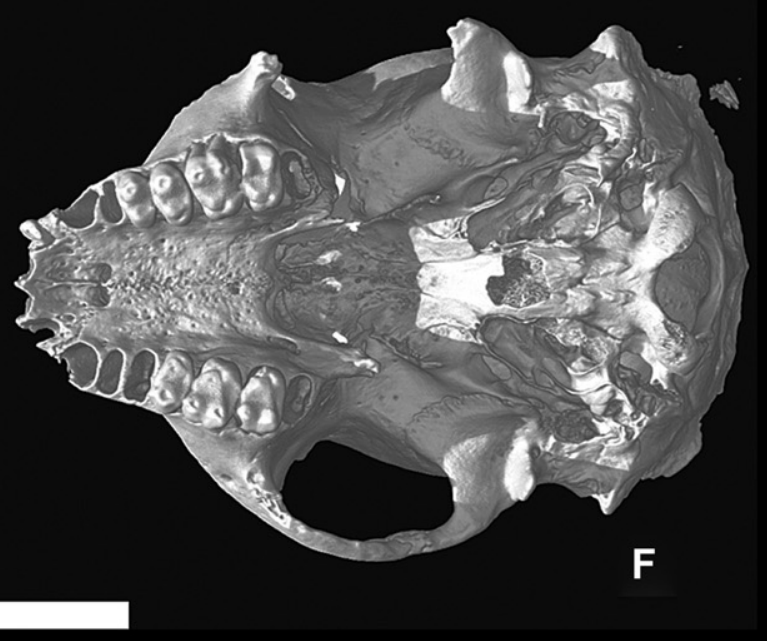

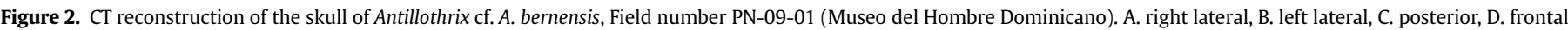
E. dorsal, F. ventral. Scale bar equals $5 \mathrm{~cm}$.

report a narrow interorbital breadth and a small postglenoid process in MHD-01. These features may be accounted for by age differences. PN-09-01 is a mature specimen, whereas MDH-01 is a late juvenile or very young adult, as indicated by epiphyses missing from the femur. Taken as a whole, the newly recognized anatomy does not support cebine affinities for Antillothrix.

Furthermore, Antillothrix does not exhibit any convincing features indicative of a relationship with Callicebus, as suggested by 

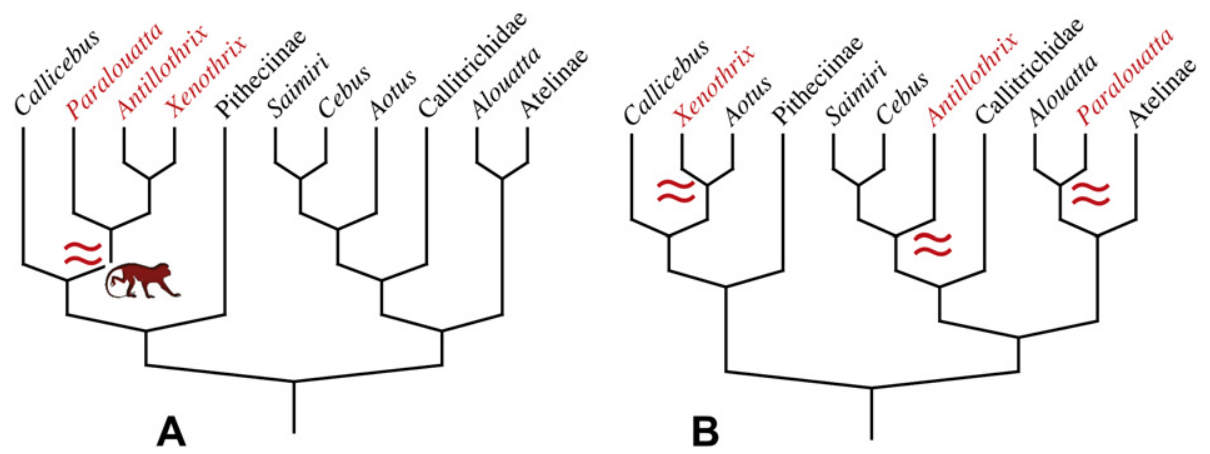

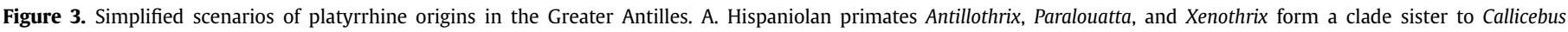

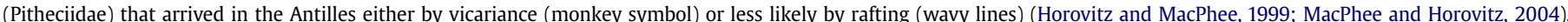

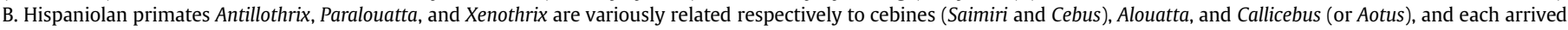
by rafting (wavy lines) (Rosenberger, 1977; Rosenberger et al., 1990; Rosenberger, 2002; Rosenberger et al., 2010).

Horovitz and MacPhee (1999). Among the derived features of Callicebus are the robust, ventrally deflected zygomatic arch, the presence of paired prominences in the middle ear where two coils of the cochlea bulge into the middle ear, and the presence of a small canine relative to premolar size (Horovitz and MacPhee, 1999). The robust zygomatic arch of Antillothrix is not ventrally displaced as in Callicebus, and only one cochlear coil bulges into the middle ear cavity.

Finally, several aspects of the anatomy of Antillothrix argue against the hypothesis that Antillothrix, Xenothrix and Paralouatta form a monophyletic clade related to the Pitheciidae, as Horovitz and MacPhee have suggested (MacPhee et al., 1995; Horovitz and MacPhee, 1999; MacPhee and Horovitz, 2004). In Xenothrix and Paralouatta, the nasal cavity is broadly expanded so that it overlaps the roots of $\mathrm{M}^{1}$ in coronal cross-section (Figure 10 in Horovitz and MacPhee, 1999). Horovitz and MacPhee (1999) suggested that a broad nasal cavity is a shared derived feature among Antillean monkeys. However, PN-09-01 evinces the typical platyrrhine narrow nasal fossa (CT scan, not illustrated).

Perhaps the most surprising feature of PN-09-01 is the arrangement of the bones at pterion. In extant platyrrhines, the parietal broadly contacts the zygomatic, excluding the frontal from contact with the sphenoid, whereas living and fossil catarrhines have a frontal-sphenoid contact. Antillothrix has the catarrhine condition. Stem platyrrhines from the early Miocene (Tremacebus and Homunculus) also have this 'catarrhine' arrangement of bones (Tauber, 1991; Kay et al., 2008), suggesting that this is the primitive condition for crown anthropoids and that perhaps Antillothrix has a deep evolutionary history independent of mainland species.

Although far more information needs to be accumulated to support it, the absence of evident synapomorphies between Antillothrix and any of the living families of platyrrhines or their extinct relatives, in combination with the presence of several important symplesiomorphies not found in crown platyrrhines, hints that Antillothrix is a stem platyrrhine unrelated to any of the living families of South American monkeys.

\section{Adaptations}

Antillothrix was a medium-sized platyrrhine (2-5 kg) (MacPhee and Meldrum, 2006). Rosenberger et al. (2010) describe a femur and ulna of the same animal, and suggest that this species was a heavily built arborealist that may have engaged in arboreal climbing. However, an undescribed distal humerus from Trou Wòch Sa Wo, Haiti, associated with teeth referable to A. bernensis, resembles that of typical platyrrhine arboreal quadrupeds (personal observation, MacPhee et al., 2007; MacPhee, 2009).
PN-09-01 evinces a steeply angled nuchal plane and airorhynchy, yielding a cranial gestalt similar to Alouatta spp. To the extent that cranial morphology is related to postcranial morphology, and in turn positional behavior, a prima facie expectation might be that Antillothrix shares some positional adaptations with howler monkeys. Although further research on the link between head posture and cranial morphology is needed, we find some support for this prima facie hypothesis. Among platyrrhines, Alouatta spp. have both the steepest nuchal planes (Hershkovitz, 1977) and a unique positional repertoire. The positional behavior of atelids, including both Alouatta and Ateles, includes a high frequency of tail suspension and tail + hindlimb suspension, postures in which the head is inferior to the body and the vertebral column is suspended beneath the tail (Schön-Ybarra and Schön, 1987). However, while tail/hindlimb suspension (without forelimb involvement) among Alouatta is high, averaging $15.4 \%$ of all posture in four studies (range: 3.8-30.7\%), suspensory behavior involving a forelimb is rare, averaging only $0.6 \%$ (range: $0-2 \%$ ) (Mendel, 1976; Schön-Ybarra, 1984; Schön-Ybarra and Schön, 1987; Bezanson, 2009) compared with $8.9 \%$ in Ateles (Youlatos, 2002; Cant et al., 2003). In forelimb-assisted suspensory modes, the spine is positioned more vertically and the head is superior to most of the body, thus requiring a more typical primate flexed neck/ shallow nuchal plane posture and morphology. Thus, the presence of an Aloutta-like nuchal angle leads us to expect that Antillothrix would have postcranial adaptations consistent with hindlimb suspension, tail suspension, or both, but that it is unlikely to have possessed Ateles-like adaptations for forelimb suspension.

The orbits of the new skull are not enlarged, indicating that Antillothrix was diurnal. The low-crowned teeth with attenuated shearing edges suggest a diet of fruit, nuts, or hard-shelled invertebrates. CT images show the molar enamel cap in Antillothrix to be very thin, inconsistent with a hard-object feeding regimen and suggesting that the diet was more likely soft fruit.

\section{Biogeographical implications}

Definitive phylogenetic placement of Antillothrix awaits a revised phylogenetic analysis combining Paralouatta, Xenothrix, PN-09-01, and MHD-01 (Rosenberger et al., 2010). Such an analysis may provide insight into the manner and timing of the arrival of mammals into the Greater Antilles. Competing models emphasize vicariance and rafting to explain how mammals reached the Antilles. Iturralde-Vinent and MacPhee (1999) postulate vicariance to explain presence of primates, sloths and rodents in the Greater Antilles. From 34 to $32 \mathrm{Myr}$, the Greater Antilles and northwestern South America were connected along an emergent Aves Ridge. This 
connection could have served as a bridge for the nonvolant mammals into the Antilles. Subsequent tectonic events separated Cuba, Jamaica, Hispaniola, and Puerto Rico with attendant vicariant biotic events.

In an alternative scenario, vertebrates entered the Antilles on rafted vegetation, and dispersal among islands was due to a combination of rafting and vicariance (Hedges, 1996, 2006). This view is supported by molecular evidence that salt water intolerant fish, lizards, snakes and amphibians entered the islands across a broad spectrum of time, some more recently and some earlier than the 34 to $32 \mathrm{Ma}$ interval (Hedges, 1996, 2006). A better understanding of the phylogenetic position of Antillothrix and the question of whether Antillean primates form a single clade should contribute significant evidence to this debate.

\section{Acknowledgements}

The authors would like to acknowledge all of those individuals who collaborated on this project. Special thanks go to the Ministerio de Cultura of the Dominican Republic, especially Lourdes Camilo de Cuello, Vice Ministra de Patrimonio Cultural; Director Juan Rodriguez Acosta (now Director General de Diversidad Cultural) and the staff of the Museo del Hombre Dominicano; and Wilfredo Feliz, Francis Soto, and the staff of the Oficina Nacional del Patrimonio Cultural Subacuático. We are grateful to the Ministerio de Medio Ambiente y Recursos Naturales, especially Eleuterio Martínez, Vice Ministro de Áreas Protegidas. We received invaluable assistance from Dora Plavetic and the United States Agency for International Development; Wyndham Viva Dominicus Beach Resort; the Project AWARE Foundation; the Armenian Nautical Association for the History of Inter-Maritime Trade; the Asociación de Hoteles La Romana-Bayahibe; the California Department of Parks and Recreation; and the Indiana University faculty and students who participated in the fieldwork. Financial support comes from National Science Foundation grant BCS-1042794 to RFK and BCS 1042835 to GWC. CT scans of PN-09-01 were performed at Pennsylvania State University with the assistance of Dr. Tim Ryan. We thank the editor and several anonymous reviewers for helpful comments and suggestions.

\section{References}

Beeker, C.D., Conrad, G.W., Foster, J.W., 2002. Taíno use of flooded caverns in the East National Park region, Dominican Republic. J. Caribbean Archaeol. 3, 1-26.

Bezanson, M., 2009. Life history and locomotion in Cebus capucinus and Alouatta palliata. Am. J. Phys. Anthropol. 140, 508-517.

Cant, J.G.H., Youlantos, D., Rose, M.D., 2003. Suspensory locomotion of Lagothrix lagothricha and Ateles belzebuth in Yasuní National Park, Ecuador. J. Hum. Evol. $44,685-699$.

Conrad, G.W., Foster, J.W., Beeker, C.D., 2001. Organic artifacts from the Manantial de la Aleta, Dominican Republic: preliminary observations and interpretations. J. Caribbean Archaeol. 2, 1-20.

Curtis, J.H., Brenner, M., Hodell, D.A., 2001. Climate change in the circum-Caribbean (late Pleistocene to present) and implications for regional biogeography. In: Woods, C.A., Sergile, F.E. (Eds.), Biogeography of the West Indies, Patterns and Perspectives, second ed. CRC Press, Boca Raton, Florida, pp. 35-54.

Fleming, K., Johnson, P., Zwartz, D., Yokoyama, Y., Lambeck, K., Chappell, J., 1998. Refining the eustatic sea-level curve since the Last Glacial Maximum using farand intermediate-field sites. Earth Planet. Sci. Lett. 163, 327-342.

Ford, S.M., Morgan, G.S., 1986. A new ceboid femur from the late Pleistocene of Jamaica. J. Vert. Paleontol. 6, 281-289.

Hedges, S.B., 1996. Historical biogeography of West Indian vertebrates. Annu. Rev. Ecol. Syst. 27, 163-196.

Hedges, S.B., 2006. Paleogeography of the Antilles and origin of West Indian terrestrial vertebrates. Annls. Mo. Bot. Gard. 93, 231-244.

Hershkovitz, P., 1977. Living New World Monkeys (Platyrrhini) with an Introduction to Primates, vol. 1. University of Chicago Press, Chicago.

Horovitz, I., 1999. A phylogenetic study of living and fossil platyrrhines. Am. Mus. Novit. 3269, 1-40.
Horovitz, I., MacPhee, R.D.E., 1999. The Quaternary Cuban platyrrhine Paralouatta varonai and the origin of Antillean monkeys. J. Hum. Evol. 36, 33-68.

Isler, K., Kirk, E.C., Miller, J.M.A., Albrecht, G.A., Gelvin, B.R., Martin, R.A., 2008 Endocranial volumes of primate species: scaling analyses using a comprehensive and reliable data set. J. Hum. Evol. 55, 967-978.

Iturralde-Vinent, M.A., MacPhee, R.D.E., 1999. Paleogeography of the Caribbean region: implications for Cenozoic biogeography. Bull. Am. Mus. Nat. Hist. 238, 1-95.

Kay, R.F., Fleage, J.G., Mitchell, T.R.T., Colbert, M.W., Bown, T.M., Powers, D.W., 2008. The anatomy of Dolichocebus gaimanensis, a primitive platyrrhine monkey from Argentina. J. Hum. Evol. 54, 323-382.

Kay, R.F., Fleagle, J.G., 2010. Stem taxa, homoplasy, long lineages and the phylogenetic position of Dolichocebus. J. Hum. Evol. 59, 218-222.

Keller, J.A., 2009. Underwater Archaeology of Padre Nuestro Cavern, Dominican Republic: Sloth Analysis. Undergraduate thesis, Underwater Archaeology. University of Indiana, Bloomington, Indiana. 63.

MacPhee, R.D.E., 2009. Insulae infortunatae: establishing a chronology for late Quaternary mammal extinctions in the West Indies. In: Haynes, G. (Ed.) American Megafaunal Extinctions at the End of the Pleistocene. Springer Science, Dordrecht, pp. 169-193.

MacPhee, R.D.E., Fleagle, J.G., 1991. Postcranial remains of Xenothrix macgregor (Primates, Xenotrichidae) and other late Quaternary mammals from Long Mile Cave, Jamaica. Bull. Am. Mus. Nat. Hist. 206, 287-321.

MacPhee, R.D.E., Horovitz, I., 2004. New craniodental remains of the Quaternary Jamaican monkey Xenothrix mcgregori (Xenotrichini, Callicebinae, Pitheciidae) with a reconsideration of the Aotus hypothesis. Am. Mus. Novit. 3434, 1-51.

MacPhee, R.D.E., Horovitz, I., Arredondo, O., Jiménez Vázquez, O., 1995. A new genus for the extinct Hispaniolan monkey Saimiri bernensis Rímoli, 1977, with notes on its systematic position. Am. Mus. Novit. 3134, 1-21.

MacPhee, R.D.E., Iturralde-Vincent, M.A., Vázquez, O.J., 2007. Prehistoric sloth extinctions in Cuba: implications of a new "last" appearance date. Caribbean J. Sci. 43, 94-98.

MacPhee, R.D.E., Iturralde-Vinent, M.A., Gaffney, E.S., 2003. Domo de Zaza, an Early Miocene vertebrate locality in south-central Cuba, with notes on the tectonic evolution of Puerto Rico and the Mona Passage. Am. Mus. Novit. 3394, 1-42.

MacPhee, R.D.E., Meldrum, D.J., 2006. Postcranial remains of the extinct monkeys of the Greater Antilles, with evidence for semiterrestriality in Paralouatta. Am. Mus. Novit. 3516, 1-37.

MacPhee, R.D.E., Woods, C.A., 1982. A new fossil cebine from Hispaniola. Am. J. Phys. Anthropol. 58, 419-436.

Mendel, F., 1976. Postural and locomotor behavior of Alouatta palliata on various substrates. Folia Primatol. 26, 36-53.

Moore, C., 1991. Cabaret: lithic workshop sites in Haiti. In: Haviser, J., Ayubi, E.N (Eds.), Thirteenth Congress of the International Association for Caribbean Archaeology. Reports of the Archaeological-Anthropological Institute of the Netherlands Antilles, No. 9. Willemstad, Curacao, pp. 92-104.

Rímoli, R., 1977. Una nueva especie de mono (Cebidae: Saimirinae: Saimiri). Cuadernos de CENDIA, vol. 242. Universidad Autonomia de Santo Domingo. 5-14.

Rivero, M., Arredondo, O., 1991. Paralouatta varonai, a new Quaternary platyrrhine from Cuba. J. Hum. Evol. 21, 1-12.

Rosenberger, A.L., 1977. Xenothrix and ceboid phylogeny. J. Hum. Evol. 6, 461-481.

Rosenberger, A.L., 1979. Phylogeny, evolution and classification of New World monkeys (Platyrrhini, Primates). Ph.D. Dissertation, City University of New York

Rosenberger, A.L., 2002. Platyrrhine paleontology and systematics: the paradigm shifts. In: Hartwig, W.C. (Ed.), The Primate Fossil Record. Cambridge University Press, Cambridge, pp. 151-159.

Rosenberger, A.L., Cooke, S.B., Rímoli, R., Ni, X., Cardoso, L., 2010. First skull of Antillothrix bernensis, an extinct relict monkey from the Dominican Republic. Proc. R. Soc. B. doi:10.1098/rspb.2010.1249.

Rosenberger, A.L., Setoguchi, T., Shigehara, N., 1990. The fossil record of callitrichine primates. J. Hum. Evol. 19, 209-236.

Ross, C.F., Ravosa, M.J., 1993. Basicranial flexion, relative brain size, and facial kyphosis in nonhuman primates. Am. J. Phys. Anthropol. 91, 305-324.

Schön-Ybarra, M.A., 1984. Locomotion and postures of red howlers in a deciduous forest-savanna interface. Am. J. Phys. Anthropol. 63, 65-76.

Schön-Ybarra, M.A., Schön, M.I., 1987. Positional behavior and limb bone adaptations in red howling monkeys (Alouatta seniculus). Folia Primatol. 49, 70-89.

Steadman, D.W., Martin, P.S., MacPhee, R.D.E., Jull, A.J.T., McDonald, H.G., Woods, C.A., Iturralde-Vinent, M., Hodgins, G.W.L., 2005. Asynchronous extinction of late Quaternary sloths on continents and islands. Proc. Natl. Acad. Sci. 102, 11763-11768.

Tauber, A., 1991. Homunculus patagonicus Ameghino, 1891 (Primates, Ceboidea), Mioceno Temprano, de la costa Atlantica Austral, Prov. de Santa Cruz, Republica Argentina, vol. 82. Academia Nacional de Ciencias de Córdoba, Argentina. 1-32.

Veloz Maggiolo, M., Vega, B., 1982. The Antillean preceramic; a new approximation. J. New World Archaeol. 5, 33-44.

Williams, E.E., Koopman, K.F., 1952. West Indian fossil monkeys. Am. Mus. Novit. $1546,1-16$

Wilson, S.M., 2007. The Archaeology of the Caribbean. Cambridge University Press, Cambridge.

Wilson, S.M., Iceland, H.B., Hester, T.R., 1998. Preceramic connections between Yucatan and the Caribbean. Lat. Am. Antiq. 9, 342-352.

Youlatos, D., 2002. Positional behavior of black spider monkeys (Ateles paniscus) in French Guiana. Int. J. Primatol. 23, 1071-1093. 